Review Article

\title{
Medicinal Effect, In Silico Bioactivity Prediction, and Pharmaceutical Formulation of Ageratum conyzoides L.: A Review
}

\author{
Jasvidianto C. Kotta $(\mathbb{D}$, Agatha B. S. Lestari $(\mathbb{D}$, Damiana S. Candrasari $(\mathbb{D}$, \\ and Maywan Hariono
}

Faculty of Pharmacy, Sanata Dharma University, Yogyakarta Campus III, Depok 55282, Indonesia

Correspondence should be addressed to Maywan Hariono; mhariono@usd.ac.id

Received 5 August 2020; Revised 22 September 2020; Accepted 26 September 2020; Published 13 October 2020

Academic Editor: Hans Sanderson

Copyright (c) 2020 Jasvidianto C. Kotta et al. This is an open access article distributed under the Creative Commons Attribution License, which permits unrestricted use, distribution, and reproduction in any medium, provided the original work is properly cited.

Goat weed (Ageratum conyzoides L.), or bandotan in Indonesia, is an herbaceous plant that broadly grows up in both subtropical as well as tropical areas. This herb contains many phytoconstituents which have many benefits in different aspects. The essential oil contains phytochemicals such as phenol, phenolic ester, and coumarin, whereas many compounds can been identified in the whole part such as terpenoid, steroid, chromene, pyrrolizidine alkaloid, and flavonoid. Empirically, this herb has been used as an antihemorrhagic, antiseptic, antileprosy, and wound-healing agent. This article reviews the potency of the herb in medication according to the chemical substances being deposited, which are collected from numerous studies, followed by its in silico bioactivity prediction as well as its pharmaceutical dosage form formulation.

\section{Introduction}

The utilization of plants as traditional medicine has been directly changing a paradigm from the use of a synthetic drug to a natural product (back to nature). Ageratum conyzoides L., namely, bandotan in Indonesia, is an herb that grows up broadly in both subtropical and tropical areas. Ageratum was named from Ancient Greek "a geras" means stay young and conyzoides derived from "konyz" means plants. This herb is genuinely from tropical America having a goat-like smell and hence called "goat weed" in English [1]. Ageratum conyzoides L. is a family of Compositae with Ageratum as the genus. Most of this genus is categorized as an herb due to its height with at least 30 species. This herb has stems and leaves covered by smooth white trichomes alongside the leaves having a short petiole. Furthermore, the leaf blade has an egg-like circular shape and $7.5 \mathrm{~cm}$ in length which is sharpening up to its terminal. The flowers consist of 8 to 15 receptacles in either purple or white color, whereas the fruits are black and small. This herb is easily found in from rice fields, yard, jungle, roadside, and riverside having a lot of sun exposure [2]. Figure 1 is the habitus of Ageratum conyzoides L. photographed in Maguwoharjo, Specific Region of Yogyakarta, Indonesia.

Ageratum conyzoides $\mathrm{L}$. is an annual herb with a long history in its benefits as a traditional medicine in many countries in the world. This weed has been known since the past time for its medicinal effect in various diseases such as common wound and the burned one, antimicrobe, arthrosis, headache, and dyspnea. The further medicinal effect has been reported such as antipneumonia, pain killer, anti-inflammatory agent, antiasthma, antispasmodic, haemostatic, gastrointestinal disorder, gynaecological disorder, antileprosy, and many other skin diseases [3].

In Africa, goat weed has been used traditionally to relieve constipation and fever and applied as a wound dressing agent as well as an antiulcer agent. In Togo, this herb is used to treat measles and snake bite, whereas in Nigeria, it is used for skin diseases, wound healing, diarrhoea, pain around the navel in children, and even used to treat HIV/AIDS [4]. The leaves are consumed as vegetables and also to prevent tetanus [5]. It is also used in the 




Figure 1: Habitus of Ageratum conyzoides L.

medication of pneumonia, antitoxin of snake venom, typhoid fever, malaria fever, sore throat, and candidiasis. The roots are used in the treatment of tumours, lithiasis, and diarrhoea in a baby. Moreover, the flower is used to relieve itching, insomnia, cough, vermifuge, tonics, and antibug parasite [6]. Besides its benefits in medication, this weed is also utilized in agriculture as an organic material which can increase a soil nutrient composition. A study evaluating this weed administration in the bokashi preparation toward the cultivation and the nutrient composition of a tomato plant demonstrates a significant effect in a mass of the tomato fruits [7].

Ageratum conyzoides L. has abroad pharmacological activities, in which one study reported that its ethanolic extract had antiurolithiatic activity which can prevent kidneys from urinary stone formation [8]. They also possess pharmacological activities such as analgesics and antipyretics $[9,10]$, anti-inflammation [10-12], antinociceptive [13], antioxidant $[11,14]$, cancer cytotoxic [15], antiulcerogenic $[16,17]$, antidiabetes [18-20], anticataleptic [21], antimicrobe [22, 23], antitumor and anticancer $[24,25]$, hepatoprotective [26, 27], anticonvulsant [28], radioprotective [29], anticoccidial [30], antidote [31], antiprotozoal [32], hematopoietic [33], allelopathic [34], bronchodilator dan uterine relaxant [35], anthelmintic [36], insecticide [37], anti-Ehrlichia [38], wound healing [39], gastroprotective [40], and anti-HIV/AIDS [41].

Ageratum conyzoides L. contains phytochemical substances such as terpenoid, sterol, flavonoid, chromene, pyrrolizidine alkaloid, coumarin, pyrrolon, and lignan [5]. Other studies also reported its essential oil phytoconstituent includes kaempferol, rhamnoside, quercetin, scutellarein, chromene, stigma-7-en-3-ol, sitosterol, stigmasterol, fumaric acid, caffeic acid, saponin, pyrrolidine alkaloid, ageratochromene derivatives, and alkane [6]. The main constituents (see Figure 2) are $\beta$-sitosterol (1), stigmasterol (2) [42], and lycopsamine (3) in which (1) and (2) are class of sterol, whereas (3) is pyrrolizidine alkaloid class [43].

A recent study has reported that Ageratum conyzoides L. leaves extract containing quercetin actively inhibited TNF- $\alpha$ during the inflammation process by degrading the collagenase of cartilage as well as the matrix metalloproteinase-9 (MMP-9). TNF- $\alpha$ is a cytokine inflammatory agent involved in osteoarthritis, which can be worsening inflammatory status in a blood vessel wall by inducing the endothelial cell damage, regulating the leucocyte activity, and releasing the cytokine as well as chemokine proinflammatory agent [44]. MMP-9 is a zinc-dependent peptidase, a member of MMP superfamily [45]. MMP is classified into five major groups according to their substrate specificity which is collagenase (MMP-1, 8, and 13), gelatinase (MMP-2 and 9), stromelysin (MMP-3, 10, 11, and 19), matrilysin (MMP-7, 12, and 18), and membrane-bound MMP (MMP-1 and 4) $[46,47]$.

Ageratum conyzoides L. contains phytochemicals with various potencies in medication, particularly in the drug discovery and development from herbal. It is also interesting to explore the pharmacological effect as well as its pharmaceutical formulation. This article reviews the active phytoconstituents of this herb which are responsible for its pharmacological activities followed by an in silico prediction of the bioactivity and the pharmaceutical preparations that have been formulated up to now.

\section{Pharmacological Activities}

2.1. Analgesic. The analgesic activity has been reported for this herb by using alcoholic extract of a whole part of the plant [10]. In vitro study demonstrated that Ageratum conyzoides L. performed analgesic activity in the ovarium of the Chinese hamster [48]. Further study by Dewan et al. also supported that the crude ethanolic extract of its leaves 




(1)

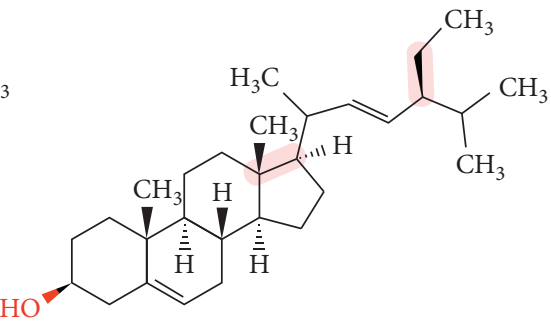

(2)



(3)

Figure 2: The molecule structure of the main constituents of Ageratum conyzoides L.

exhibited analgesic activity in mice induced by acetic acid [49]. During inflammation, the elevation of prostaglandin levels affects poor pain by enhancing the capillary permeability [50]. At this stage, the synthesis of prostaglandin is inhibited through the mechanism of peripheral pain inhibition leading to its analgesic effect [51]. A clinical study has been carried out in patients with arthritis using a water extract from the whole part of the Ageratum. The result shows that $66 \%$ of the patients are relieved from their pain, and their articulation mobility was improved by $24 \%$ without side effects [52].

A study supported the previous study by exhibiting a significant analgesic activity of water extract from the whole part of Ageratum conyzoides L. using the tail flick method [9]. The phytochemicals of Ageratum conyzoides L. essential oils employing precocene I (4), precocene II (5), and 6-vinyl7-methoxy-2,2-dimethyl chromene (VMDC) (6) (see Figure 3) are a member of chromene compounds, responsible for its analgesic bioactivity [53]. Furthermore, the alkaloid and flavonoid in the oil can block the pain perception [54], whereas other secondary metabolites such as tannin, saponin, and terpenoid also have been reported having pharmacological activity [55].

2.2. Anti-Inflammatory Agent. The ethanolic extract of ageratum can reduce inflammation significantly, which is induced by carrageenan and histamine activities. The phytochemical substances playing a role in this activity are quercetin, kaempferol, glycoside, tannin, and other polyphenolic compounds [56]. The potential anti-inflammatory agent from this herb due to the inflammation was induced by raw oil which is further characterized by DNA damage in a male Wistar mouse sperm [57]. In vitro study of this methanolic extract also showed anti-inflammatory activity, which supports the previous study [58]. A study related to this standardized herbal extract by $5^{\prime}$-methoxynobiletin which is a class of polymethoxyflavones (see Figure 4) showed some benefits to overcome pain and inflammation. This provides a new innovation in the development of a new drug to treat inflammation-related diseases such as rheumatoid arthritis [13].

One study reported that the anti-inflammatory effect of goat weed depended on the flavonoid fraction which influenced the protein expression from the inflammatory gen [11]. In particular, the flavonoid glycoside fraction of this herb showed a very potent anti-inflammatory activity [12]. In a mouse pleural cavity, the inflammatory response is reduced by administrating this herb's extract, by blocking the entry of leucocyte and the protein exudate concentration, and also diminishing the level of the inflammatory mediator [59].

2.3. Antimicrobial Effect. The antimicrobial activity in both methanol and ether extract of Ageratum conyzoides L. has been reported. This herb contains antimicrobial components which are useful against oxidase enzyme in bacteria which is a pathogen and related to the systemic infection, leading to deadly effect in animal and human [22]. Another study also explores that essential oil in Ageratum conyzoides L. had a potential antimicrobial towards Escherichia coli and Klebsiella pneumoniae (uropathogenic bacteria) and, therefore, is useful in the prophylactic of urinary tract infection [60].

The antimicrobial activity assay from both root and leaf extracts demonstrates antibacterial and antifungal activities against the isolate of Bacillus subtilis (Gram positive), Escherichia coli, Klebsiella pneumoniae, Pseudomonas aeruginosa, Staphylococcus aureus, Salmonella typhi (Gram negative), and fungal strain, i.e., Aspergillus niger, Candida albicans, Penicillium notatum, and Rhizopus stolon [61]. The essential oil of Ageratum conyzoides L. leaves has antibacterial activity in inhibiting Salmonella enteritidis [62]. The leaves and stem extract of Ageratum conyzoides L. can be used as a broad-spectrum antibacterial agent. Moreover, the in vitro study from the methanolic extract and $n$-hexane extract of Ageratum conyzoides L. showed antifungal activities against Fusarium solani [63]. The leaves and stem extracts of Ageratum conyzoides L. contain phytochemical substances such as flavonoid, saponin, alkaloid, tannin, and phenol, which showed antibacterial activity depends on its concentration against the bacterial isolate [64].

2.4. Antioxidant. The ethanolic extract of leaves and flowers from Ageratum conyzoides L. demonstrated antioxidant activities against DPPH (1,1-diphenyl-2-picryl hydrazyl) to scavenge the free radicals. Those antioxidant activities are due to the presence of phytochemicals such as flavonoids and phenol [65]. This claim was supported by the study of the potent antioxidant from methanolic extract of Ageratum conyzoides L. stems depending on the phenolic components [15]. The result shows that the leaves of the ethanolic extract have antioxidant activity which is higher than its water extract. This extract has a strong natural antioxidant effect 
<smiles>COc1cc2c(cc1C=O)C=CC(C)(C)O2</smiles>

(4)<smiles>COc1cc2c(cc1OC)OC(C)(C)C=C2</smiles>

(5)

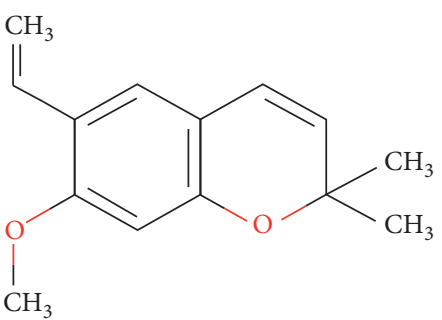

(6)

Figure 3: Molecule structure of chromene which are responsible for the analgesic activity of Ageratum conyzoides L.<smiles>COc1cc(-c2cc(=O)c3c(OC)c(OC)c(OC)c(OC)c3o2)cc2c1OCO2</smiles>

Figure 4: Molecule structure of $5^{\prime}$-methoxynobiletin which is a benefit for its anti-inflammatory effects of Ageratum conyzoides L.

against the free radical and also used in the treatment of erectile dysfunction induced by oxidative stress [14].

Further study about the antioxidant activity from the leaves ethanolic extract has also supported the previous study [66]. On the one hand, the methanolic extract shows much higher antioxidant activity than its essential oils [67]. On the other hand, Ageratum conyzoides L. has a positive effect in the redox system when it is exposed to diabetic rats induced by streptozotocin, while increasing the glycaemic status of those rats [68].

2.5. Antimalaria. A study shows that the water extract of Ageratum conyzoides L. has a potency to increase the antimalaria activity of chloroquine and artesunate in the plasmodial induced-rats [69]. The phytochemical responsible for the antimalarial activities are alkaloid, glycoside, flavonoid, saponin, tannin, and resin. In this study, the leaves extract as well as its fraction show a significant antimalarial activity toward parasite plasmodium as confirmed by in vitro or in vivo model in mice [69].

2.6. Agent for Metabolic and Degenerative Diseases. Ethanolic extract of Ageratum conyzoides L. demonstrates antidiarrhoea and antidiabetic activities in albino rats [19]. The water extract also showed activity as hypoglycemic in diabetic rats induced by normoglycemic and streptozotocin [20]. Other studies also investigated the antidiabetic activity of the leaves water extract by exhibiting a positive effect on hypoglycemic activities [70]. The extract of goat weed has a hypoglycemic effect which is significantly comparable to glibenclamide [71]. Another study also reported that $A g$ eratum conyzoides $\mathrm{L}$. demonstrates both hypoglycemic as well as hypolipidemic effects in rats [72].
Ageratum conyzoides $\mathrm{L}$ has reported having antidiarrhoea activity through its antispasmodic activity and the solid formation of the feces mass. The ethanolic extract has potency as the gastroprotective agent in rats which could be mediated by its antioxidant properties, by blocking the calcium channel obstruction and its antiserotonergic properties [40].

\section{Toxicological Activities}

Hydroalcoholic extract of Ageratum conyzoides L. could be toxic to the liver, kidneys, and blood cells after long-term exposure as confirmed by both in vivo and in vitro assay [4]. Therefore, the use of Ageratum conyzoides L. in a longer duration should be carefully managed. This toxic effect could be due to the alkaloid total especially to pyrrolizidine. The hepatotoxic effect after oral administration of the leaves ethanolic extract has been shown in Wistar albino rats upon three regimen doses, i.e., 200,400 , and $600 \mathrm{mg} / \mathrm{kg}$ of bodyweight within 21 days. The experiment shows that the total protein serum and liver alanine aminotransferase (ALT), aspartate aminotransferase (AST), and alkaline phosphatase (ALP) did not significantly change; therefore, it can be concluded that the extract is not toxic to the liver at those respective doses [73].

A study related to the toxicological extract of the leaves has been carried out in rats by showing $\mathrm{LD}_{50}$ extract equal to $600 \mathrm{mg} / \mathrm{kg}$ bodyweight. The postmortem report shows an alteration in the intestine liver and kidneys, bleeding at subcontracted muscles alongside intestinal tracts, paracentral hepatic necrosis, and tubulin proximal convulsion. However, in the chronic toxicity study, the extract did not show a significant effect in the bodyweight elevation, haematology, its alanine amino serum, the aspartate aminotransferase, and its blood nitrogen urea. This however 
depends on the dose which affected the histopathological intestine liver and kidneys [74].

\section{In Silico Prediction of Molecular Pharmacology Mechanism}

The living organism is graded in seven levels according to their sizes from the smallest to the biggest as follows: ionic, atomic, molecular, cellular, tissue, organ, and body [75]. In the past, the pharmacological activity of the drug was mainly examined using animal experiments [76]. However, due to the ethical clearance, the use of animal in a preliminary study which means at organ and body levels has been tightly restricted [77]. The technology of cell culture and tissue engineering then significantly overcomes the ethical issue; however, at the tissue and cellular levels, there are still a lot of pathways of pathogenesis which made the mechanism become more complicated [78]. Later on, modern drug discovery has been utilizing protein, signal transduction, genes, and nucleic acid as the therapeutic target at the molecular level. This leads to a more selected target because the drug-target interaction can be elucidated specifically [79]. The advanced bioinformatics alongside information technology facilitated the study of drug-target interaction at the molecular level using the in silico (computational) method before applying the in vitro experiment [80].

This section will predict the interactions of seven representative compounds of Ageratum conyzoides with seven proteins from respected biological activities as described before. Table 1 organizes seven compounds which could affect the corresponding protein target and also corresponds to the diseases of interest. Therefore, this prediction could inform on how Ageratum conyzoides works against pathologic conditions at the molecular level. The in silico method being used is molecular docking as supplemented in Supplementary Materials (S1). The seven compounds (ligands) are precocene I, precocene II, VMDC, beta-sitosterol, stigmasterol, polymethoxyflavone, and pyrrolizidine, whereas the seven proteins are human tyrosinase $(5 \mathrm{~m} 8 \mathrm{~s})$ [81], Plasmodium falciparum ornithine delta-aminotransferase (3lg0) [82], Mus musculus cyclooxygenase-2 (4cox) [83], E. coli 4-diphosphodicytidyl-2-C-methylerythritol synthase (1i52) [84], glycoside hydrolase family 97 from Bacteroides thetaiotaomicron (2zq0) [85], human p53 (4ibu) [86], and human MMP-9 (116j) [87].

Tyrosinase is an enzyme associating with the oxidation process due to its function in melanin or other pigment production from tyrosine. A compound that can inhibit tyrosinase could be related to its antioxidant properties [88]. Ornithine delta-aminotransferase has a function to produce nonessential amino acid proline from ornithine which is involved in the plasmodium life cycle that leads to malaria disease [89]. Cyclooxygenase- 2 catalyses the conversion of arachidonic acid into inflammatory mediators such as prostaglandin, prostacyclin, and leukotriene leading to inflammation [90]. 4-Diphosphodicytidyl-2-C-methylerythritol synthase is an enzyme expressed by the bacteria cell of E. coli having a function to catalyse the formation of isoprenoid which is one of the components in bacteria building block [91]. Glycoside hydrolase family 97 hydrolyses the glycosidic bond between oligosaccharide and polysaccharide into monosaccharide leading to blood glucose upregulation associating with diabetes [92]. p53 is a gene suppressing a tumour gene by upregulating apoptosis. This gene is often associated with cancer cell proliferation [93]. MMP-9 is gelatinase having a function as introduced before, related to inflammation, wound healing, and cancer metastasis [94-96].

Table 2 tabulates the molecular docking results performing binding energy of seven ligands identified in $\mathrm{Ag}$ eratum conyzoides in which the lower energy (more negative) is the stronger binding with the respected protein. In human tyrosinase $(5 \mathrm{~m} 8 \mathrm{~s})$, the chromene compound class (precocene I, precocene II, and VMDC) has better interactions than other compounds, whereas the sterol compound class predominates the better interactions with ornithine delta-aminotransferase than chromene, flavonoid, and alkaloid. In cyclooxygenase-2, either sterol of flavonoid has a better interaction than others, whereas flavonoid is the best ligand to interact with 4-diphosphodicytidyl-2-Cmethylerythritol synthase. In contrast, the chromene and alkaloids are even better in interacting with glycoside hydrolase than sterol and flavonoid. Compared with other proteins, all ligands have relatively poor interactions with the p53 gene, whereas the opportunity of Ageratum conyzoides as an MMP-9 inhibitor could be due to the presence of sterol and flavonoid than alkaloid and chromene.

Figure 5 visualizes the binding pose of seven ligands as the docking results in the respected proteins/gene. Although the binding energy is within the broad range, all ligands occupied the same pocket of human tyrosinase. In contrast, the ligands are divided into three binding clusters in the pocket of the human p53 gene. As happened in human p53, the ligands have two different binding positions in the pocket of glycoside hydrolase.

The binding pose of all ligands is quite stable in the MMP-9 pocket site along with their binding energies. In contrast, the ligands are divided into two binding site positions when they are docked into the cyclooxygenase-2 pocket. Interestingly, two ligands, i.e., beta-sitosterol and polymethoxyflavone (5-methoxynobiletin) performed two lowest binding energies $(-8.9$ and $-8.5 \mathrm{kcal} / \mathrm{mol}$, respectively) when they interacted with cox-2. This means that both ligands bind to the cox-2 binding site stronger than other ligands. Although both ligands have a similar low binding energy, however, their binding positions are different which could lead to a different biological activity (see Figure 6).

In microorganisms such as E. coli and P. falciparum, the ligands are occupying the same binding pocket of 4diphosphodicytidyl-2-C-methylerythritol synthase and ornithine delta-aminotransferase, respectively. Moreover, the chance of Ageratum conyzoides to be antibacterial and antimalarial agents is opened due to the relatively lower binding energies as well as its stable conformations during interaction with the corresponding proteins (see Figure 7). 
TABLE 1: Seven compounds which would be predicted to interact molecularly with the respective protein target leading to their drug effect to the corresponding diseases.

\begin{tabular}{|c|c|c|}
\hline Ligands & Protein target & Disease target \\
\hline Precocene I & $\begin{array}{c}\text { Cyclooxygenase- } 2 \\
\text { MMP-9 }\end{array}$ & $\begin{array}{c}\text { Pain } \\
\text { Rheumatoid arthritis }\end{array}$ \\
\hline Precocene II & $\begin{array}{c}\text { Cyclooxygenase-2 } \\
\text { MMP-9 } \\
\end{array}$ & $\begin{array}{c}\text { Pain } \\
\text { Rheumatoid arthritis }\end{array}$ \\
\hline VMDC & $\begin{array}{c}\text { Cyclooxygenase-2 } \\
\text { MMP-9 }\end{array}$ & $\begin{array}{c}\text { Pain } \\
\text { Rheumatoid arthritis }\end{array}$ \\
\hline Beta-sitosterol & $\begin{array}{c}\text { Tyrosinase } \\
\text { Glycoside hydrolase } \\
\text { 4-Diphosphodicytidyl-2-C-methylerythritol }\end{array}$ & $\begin{array}{c}\text { Antioxidant } \\
\text { Hyperglycemic } \\
\text { Antibacteria }\end{array}$ \\
\hline Stigmasterol & $\begin{array}{c}\text { Human p53, MMP-9 } \\
\text { Tyrosinase } \\
\text { Glycoside hydrolase } \\
\text { 4-Diphosphodicytidyl-2-C-methylerythritol }\end{array}$ & $\begin{array}{c}\text { Cancer } \\
\text { Antioxidant } \\
\text { Hyperglycemic } \\
\text { Antibacteria }\end{array}$ \\
\hline 5-Methoxynobiletin & $\begin{array}{c}\text { MMP-9 } \\
\text { Ornithine delta-aminotransferase }\end{array}$ & $\begin{array}{c}\text { Rheumatoid arthritis } \\
\text { Antimalaria }\end{array}$ \\
\hline Lycopsamine & Ornithine delta-aminotransferase & Antimalaria \\
\hline
\end{tabular}

\section{Pharmaceutical Formulation}

The formulation utilizing extract from goat weed has been carried out. Extract of goat weed could be developed into a polyherbal formulation as the wound-healing agent through a topical route. This formulation is composed of Ageratum conyzoides, Ficus religiosa, Curcuma longa, and Tamarindus indica. The result showed that the polyherbal formulation has a good wound-healing effect in rats [97].

The next study also developed the formulation of emulsifiable concentrate (EC) from the aerial part extract of Ageratum conyzoides L. using a nontoxic solvent and emulsifying agent. This study was focused on the evaluation of such formulations as an antimicrobial agent. A diverse solvent has been used to extract the materials, including dichloromethane, methanol, and $n$-hexane. The identified compounds in the extract elucidated using gas chromatography-mass spectroscopy (GC-MS) showing bioactivities. The developed EC was found more active than its crude extract against bacteria and fungus [98].

The success of EC formulation is developed from the aerial part making further formulation from this herb to be designed in a pharmaceutical gel dosage form. This dosage form then tested its activity against Staphylococcus epidermidis and Propionibacterium acnes. In this work, Ageratum conyzoides was extracted using the maceration method in ethanol $90 \%$. The antibacterial activity was determined using the disc paper diffusion method, whereas the minimum inhibitory concentration (MIC) and minimum bactericidal concentration $(\mathrm{MBC})$ were determined using the microdilution method. The extract was formulated into the gel basis containing various concentrations of sodium carboxymethyl cellulose (CMC) and hydroxypropyl methylcellulose (HPMC). The result showed that the dosage form performed antibacterial activity against Staphylococcus epidermidis and Propionibacterium acnes with a MIC value of $2.5 \%$. The best result was performed by the formula containing $4 \%$ of the sodium CMC and $2.5 \%$ of the extract. The antibacterial activity of the gel was able to inhibit $14.7 \pm 2.3 \mathrm{~mm}$ and $15.43 \pm 1.6 \mathrm{~mm}$ in the zone of the growth of Staphylococcus epidermidis and Propionibacterium acnes, respectively [99].

A study related to the gel formulation was also developed by Taufid and Ameilia. In this study, the extract was prepared by macerating Ageratum conyzoides L. using ethanol $96 \%$. The gel was composed of sodium CMC as the bases using three different extract concentrations, i.e., $2.5 \%, 5 \%$, and $7.5 \%$, accordingly. The physical quality of the gel was evaluated employing physical appearance, homogeneity, $\mathrm{pH}$, and its dispersion force. The gel met the requirement as a good dosage form, in particular with its dispersion force within $3-5 \mathrm{~cm}$ [100].

A current study has developed a novel formulation which is nanoemulgel from Ageratum conyzoides L. extract (ACE) combined with Oldenlandia corymbosa $L$ extract (OCE), indicated as an anti-inflammatory agent. Nanoemulgel ACE-OCE has been developed either individually or in combination, having a good physical characteristic and promising effect from its activity as an anti-inflammatory agent for osteoarthritic therapy [101]. Table 3 organizes the type of extracts that have been formulated in pharmaceutical dosage forms regarding their corresponding active ingredient being studied previously for their molecular interaction in the protein targets of interest.

\section{Discussion}

The aerial part of Ageratum conyzoides has been elaborated above, as this plant has the potential to be developed as a modern drug. The identified compound has extensively studied its pharmacological activity as a pain killer, antiinflammatory, antioxidant, antimalarial, antidiabetes, anticancer, and antibacterial agent. The most-reported compounds being studied, having a responsibility toward its pharmacological activity, are classes of chromene, sterol, flavonoid, and alkaloid. 
TABLE 2: Docking results performing binding energy of ligands from Ageratum conyzoides interacting with seven proteins playing a role in diverse pathologic condition.

\begin{tabular}{|c|c|c|c|c|c|c|c|}
\hline \multirow{2}{*}{ Ligands } & \multicolumn{7}{|c|}{ Binding energies $(\mathrm{kcal} / \mathrm{mol})$} \\
\hline & $5 \mathrm{~m} 8 \mathrm{~s}$ & $3 \lg 0$ & $4 \operatorname{cox}$ & $1 \mathrm{i} 52$ & $2 \mathrm{zq} 0$ & $4 \mathrm{ibu}$ & $116 \mathrm{j}$ \\
\hline Precocene I & -7 & -7.2 & -7.7 & -6.2 & -6.4 & -4.2 & -5.1 \\
\hline Precocene II & -6.8 & -7 & -7.6 & -6 & -6 & -4.3 & -5.3 \\
\hline VMDC & -7.4 & -8 & -7.5 & -6.3 & -6.1 & -4.6 & -5.3 \\
\hline Beta-sitosterol & 1.8 & -8.3 & -8.9 & -6.6 & -2.5 & -2.7 & -6.9 \\
\hline Stigmasterol & -2.8 & -8.4 & -7.4 & -6.8 & -4 & -3 & -6.6 \\
\hline 5-Methoxynobiletin & -4.7 & -5.9 & -8.5 & -7 & -3.5 & -1.5 & -6.2 \\
\hline Lycopsamine & -5.6 & -4.5 & -5.8 & -5.1 & -6.1 & -4.3 & -5.1 \\
\hline
\end{tabular}

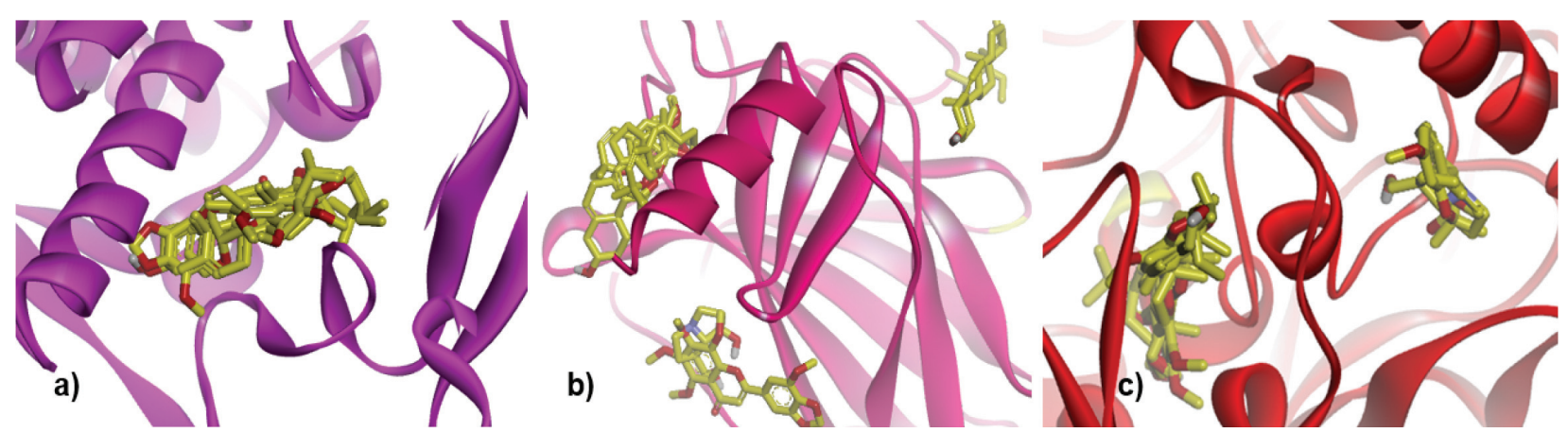

FIGURE 5: Binding pose of seven ligands identified from Ageratum conyzoides in the pocket of (a) human tyrosinase, (b) human p53, and (c) glycoside hydrolase. The protein was presented in a ribbon model, whereas the ligands were in a stick form.

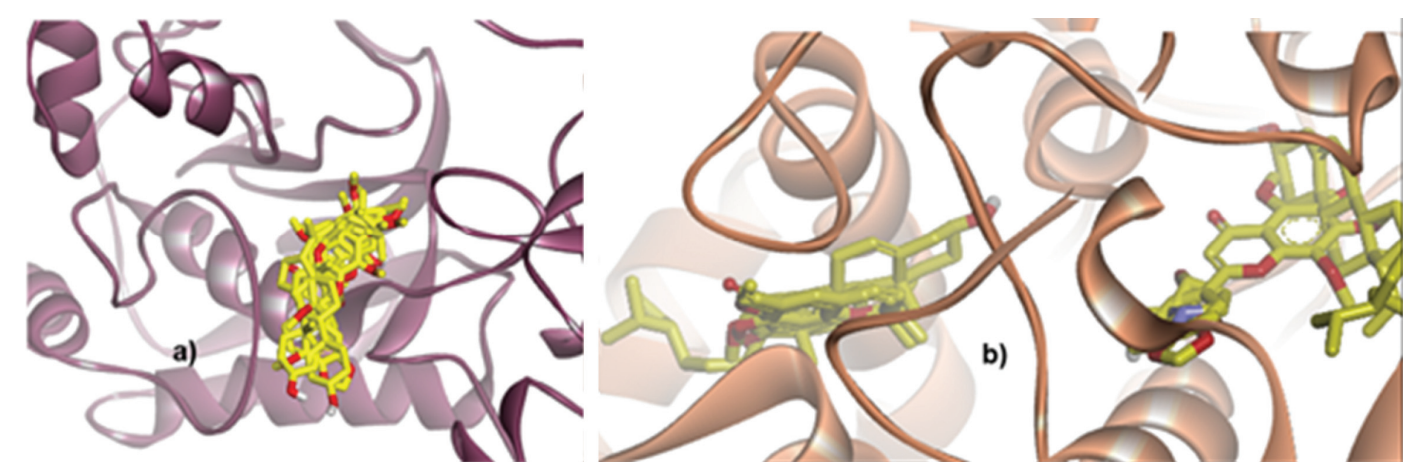

Figure 6: Binding pose of seven ligands identified from Ageratum conyzoides in the pocket of (a) MMP-9 and (b) cyclooxygenase-2. The protein was presented in a ribbon model, whereas the ligands were in a stick form.
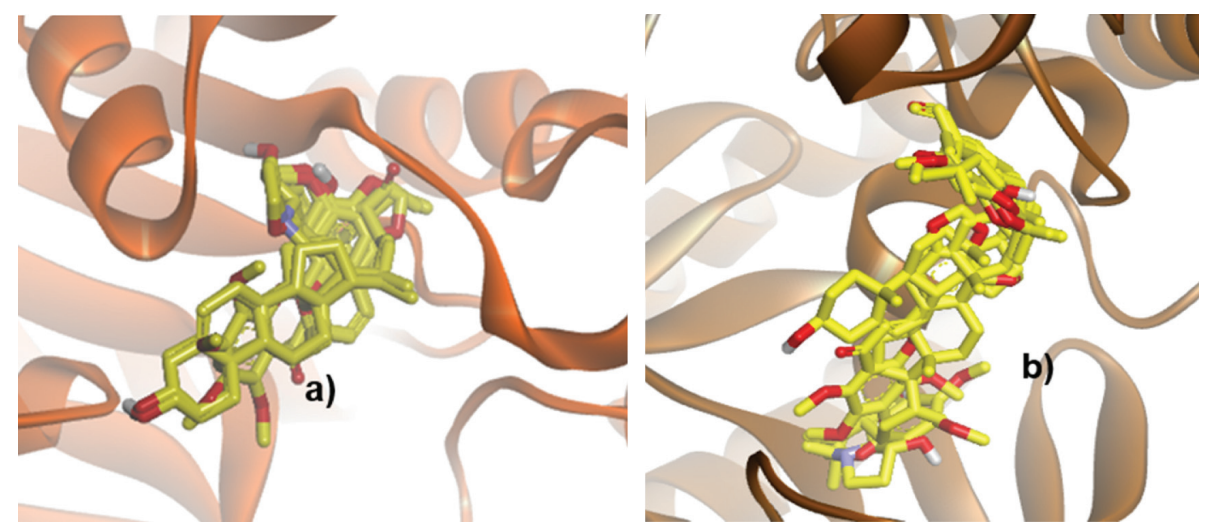

FiguRe 7: Binding pose of seven ligands identified from Ageratum conyzoides in the pocket of (a) 4-diphosphodicytidyl-2-C-methylerythritol synthase and (b) ornithine delta-aminotransferase. The protein was presented in a ribbon model, whereas the ligands were in a stick form. 
TABLE 3: Types of ageratum extract formulated in pharmaceutical dosage form, the respective active ingredients, and the protein target being studied.

\begin{tabular}{lcccc}
\hline Part & $\begin{array}{c}\text { Extract } \\
\text { Solvent }\end{array}$ & Formulation & Active ingredient & Protein target \\
\hline Root & Ethanol & Ointment & Alkaloids & Ornithine delta-aminotransferase \\
\hline Aerial part & Methanol & $\begin{array}{l}\text { Emulsifiable } \\
\text { Concentrate }\end{array}$ & $\begin{array}{l}\text { Precocene I } \\
\text { Precocene II }\end{array}$ & Cyclooxygenase-2, MMP-9 \\
\hline Aerial part & Dichloromethane & $\begin{array}{l}\text { Emulsifiable } \\
\text { Concentrate }\end{array}$ & $\begin{array}{l}\text { Precocene I } \\
\text { Precocene II }\end{array}$ & Cyclooxygenase-2, MMP-9 \\
\hline Aerial part & Hexane & Emulsifiable concentrate & $\begin{array}{c}\text { Precocene I } \\
\text { Precocene II }\end{array}$ & Cyclooxygenase-2, MMP-9 \\
\hline Leaves & Ethanol & Gel & Alkaloids, flavonoids & Ornithine delta-aminotransferase, MMP-9 \\
\hline Aerial part & Ethanol & Nanoemulgel & Alkaloids, flavonoids & Ornithine delta-aminotransferase, MMP-9 \\
\hline
\end{tabular}

TABLE 4: Correlation between in silico and the classical study of seven compounds identified in Ageratum in which most of compounds have a positive correlation except for lycopsamine.

\begin{tabular}{lccc}
\hline Compounds & In silico methods & Classical methods & Therapy \\
\hline Precocene I & + & + & Pain management, antidiabetes \\
Precocene II & + & + & Pain management, antidiabetes \\
VMDC & + & + & Pain management, antidiabetes \\
Beta-sitosterol & + & + & Anticancer \\
Stigmasterol & + & + & Anticancer \\
5-Methoxynobiletin & + & + & Antibacterial agent \\
Lycopsamine & - & + & Antimalaria \\
\hline
\end{tabular}

The chromene compounds studied as an analgesic drug are corresponding with its in silico prediction in which precocene I, precocene II, and VMDC performed relatively good energy bindings in cox-2. Furthermore, polymethoxyflavone studied as anti-inflammatory agents is exhibiting better binding energy with cox-2 than chromene and other ligands. Flavonoids such as polymethoxyflavone also were studied as an antibacterial against $E$. coli which could be due to the 4-diphosphodicytidyl-2-C-methylerythritol synthase inhibition. In contrast, the interaction of pyrrolizidine alkaloids with ornithine delta-aminotransferase seems like not related to its antimalarial property; therefore, there should be other proteins/genes expressed by $P$. falciparum abled to be targeted in claiming the antimalarial agent. In the antidiabetic activity, the hypoglycemic effect of Ageratum conyzoides could be due to the presence of chromene compounds. In the in silico prediction, precocene I, precocene II, and VMDC show lower binding energy than other compounds in Ageratum. The activity of goat weed as an MMP-9 inhibitor could be due to the sterol compounds since this class exhibits relatively good binding energies in the in silico prediction. This activity could associate with its pharmacological activity as an anticancer. The correlation between in silico and the classical study is highlighted in Table 4 .

In the topical pharmaceutical formulation aspect, Ageratum combined with other herbals has been well applied. The choice in the topical route could be due to some reasons. First, this herb is most likely indicated as a wound-healing agent either in the common wound or burned, antimicrobe, and arthrosis, by a topical route, and the drug would be interacting faster with the target site via local effect. Second, the topical route is chosen according to the toxicological effect of the liver, kidneys, and blood cells after long-term exposure as confirmed by both in vivo and in vitro assay. Last but not least, the unpleasant smell of goat weed could be the reason why the nonsystemic route such as topical is preferable for its pharmaceutical dosage form. The gel formulation is suitable for its indication in burns healing process due to its water base preparation giving cool and comfortable feeling during application. Moreover, the waterbased gel may easily be absorbed by the wound dissolving like an interface between the gel and the wound excretes.

\section{Conclusion}

Based on the review, Ageratum conyzoides L. has a great deal of potency and clinical effect which is beneficial. Further efforts should be continued to decide the toxicity and adverse side effect of this herbal extract in the clinical study because there have not studied the specific toxicity as well as its adverse side effect. To date, there has not been much development in the formulation of this herb by using more advanced technology which can increase the economic value of this plant. Therefore, this could be a good innovation in the development of dosage form formulation utilizing $\mathrm{Ag}$ eratum conyzoides $\mathrm{L}$.

\section{Data Availability}

This is a review article; hence, there is no data availability applied by the authors. 


\section{Conflicts of Interest}

The authors declare that there are no conflicts of interest regarding the publication of this paper.

\section{Acknowledgments}

This project was financially supported by the Sanata Dharma University Internal Research Grant 2020 (no. 006/LPPM USD/I/2020). The authors acknowledge Molecular Graphic Lab at Scripps Research Institute for the open-source program for doing molecular docking using AutoDock Vina (http://vina.scripps.edu/).

\section{Supplementary Materials}

S1. The procedure of molecular docking using AutoDock Vina Program. (Supplementary Materials)

\section{References}

[1] A. L. Okunade, "Ageratum conyzoides L. (Asteraceae)," Fitoterapia, vol. 73, no. 1, pp. 1-16, 2002.

[2] M. C. Ashande, P. T. Mpiana, and K. N. Ngbolua, "Ethnobotany and pharmacognosy of Ageratum conyzoides L. (Compositae)," Journal of Advancement in Medical and Life Sciences, vol. 2, no. 4, pp. 1-6, 2015.

[3] A. Kamboj and A. K. Saluja, "Ageratum conyzoides L.: a review on its phytochemical and pharmacological profile," International Journal of Green Pharmacy (IJGP), vol. 2, no. 2, 2008.

[4] A. Diallo, K. Eklu-Gadegkeku, A. Agbono et al., "Acute and sub-chronic (28-day) oral toxicity studies of hydroalcohol leaf extract of Ageratum conyzoides L. (Asteraceae)," Tropical Journal of Pharmaceutical Research, vol. 9, no. 5, 2010.

[5] R. Kaur and N. K. Dogra, "A review on traditional uses, chemical constituents and pharmacology of Ageratum conyzoides L. (Asteraceae)," International Journal of Pharmaceutical and Biological Science Archive, vol. 5, no. 5, pp. 33-45, 2014.

[6] N. Yadav, S. A. Ganie, B. Singh et al., "Phytochemical constituents and ethnopharmacological properties of Ageratum conyzoides L." Phytotherapy Research, vol. 33, no. 9, pp. 2163-2178, 2019.

[7] A. Anhar, R. Junialdi, A. Zein et al., "Growth and tomato nutrition content with bandotan (Ageratum conyzoides L) bokashi applied," IOP Conference Series: Materials Science and Engineering, vol. 335, no. 1, 2018.

[8] S. Muthukrishnan, "Antiurolithiatic effect of various whole plant extract of Ageratum conzoides Linn. on ethylene glycol induced urolithiasis in male wistar albino rats," International Journal of Pharmaceutical Sciences and Research, vol. 5, no. 10, p. 4499, 2014.

[9] S. L. RK, V. Valte, and Z. Sailo, "A study of the analgesic effect of aqueous extract of the whole plant of Ageratum conyzoides Linn. in experiments on animal models," Indian Journal of Pharmacy and Pharmacology, vol. 6, no. 1, pp. 28-32, 2019.

[10] A. Rahman, N. Akter, H. Rashid et al., "Analgesic and antiinflammatory effect of whole Ageratum conyzoides and Emilia sonchifolia alcoholic extracts in animal models," African Journal of Pharmacy and Pharmacology, vol. 6, no. 20, pp. 1469-1476, 2012.
[11] E. M. Galati, N. Miceli, M. F. Taviano, R. Sanogo, and E. Raneri, "Anti-inflammatory and antioxidant activity of Ageratum conyzoides," Pharmaceutical Biology, vol. 39, no. 5, pp. 336-339, 2001.

[12] N. E. Awad, H. A. Kassem, A. A. Matloub et al., "Anti-inflammatory evaluation of Ageratum conyzoides L. Leaves," Planta Medica, vol. 77, no. 12, 2011.

[13] L. G. Faqueti, V. Brieudes, M. Halabalaki et al., "Antinociceptive and anti-inflammatory activities of standardized extract of polymethoxyflavones from Ageratum conyzoides," Journal of Ethnopharmacology, vol. 194, pp. 369-377, 2016.

[14] F. O. Adetuyi, K. O. Karigidi, E. Akintimehin, and O. N. Adeyemo, "Antioxidant properties of Ageratum conyzoides L. Asteraceae leaves," Bangladesh Journal of Scientific and Industrial Research, vol. 53, no. 4, pp. 265-276, 2018.

[15] F. Nasrin, "Antioxidant and cytotoxic activities of Ageratum conyzoides stems," International Current Pharmaceutical Journal, vol. 2, no. 2, pp. 33-37, 2013.

[16] M. Prasenjit, G. Tanaya, and M. Prasanta Kumar, "Seasonal variation in anti-ulcerogenic activity of Ageratum conyzoides L. leaves," International Journal of Biopharmaceutics, vol. 7, pp. 63-68, 2016.

[17] A. Aladdin, "Antiulcerogenic activity of Ageratum conyzoides: a review," Journal of Biotechnology Science Research, vol. 4, no. 3, p. 204, 2017.

[18] O. S. Agunbiade, O. M. Ojezele, J. O. Ojezele, and A. Y. Ajayi, "Hypoglycaemic activity of Commelina africana and Ageratum conyzoides in relation to their mineral composition," African Health Sciences, vol. 12, no. 2, pp. 198-203, 2012.

[19] M. A. Rahman, R. Sultana, R. Akter et al., "Antidiarrheal and antidiabetic effect of ethanol extract of whole Ageratum conyzoides L. in albino rat model," African Journal of Pharmacy and Pharmacology, vol. 7, no. 23, pp. 1537-1545, 2013.

[20] N. Nyunaï, N. Njikam, E. Abdenneb, J. T. Mbafor, and D. Lamnaouer, "Hypoglycaemic and antihyperglycaemic activity of Ageratum conyzoides L. in rats," African Journal of Traditional, Complementary and Alternative Medicines, vol. 6, no. 2, pp. 123-130, 2009.

[21] M. V. Tote, N. B. Mahire, A. Jain et al., "Effect of Ageratum conyzoides Linn on clonidine and haloperidol induced catalepsy in mice," Pharmacologyonline, vol. 2, pp. 186-194, 2009.

[22] B. R. Singh, V. O. R. Kumar, D. Sinha et al., "Antimicrobial activity of methanolic extract and ether extract of Ageratum conyzoides," Pharmaceutica Analytica Acta, vol. 7, no. 3, p. 471, 2016.

[23] R. N. Ndip, A. N. Ajonglefac, T. Wirna et al., "In-vitro antimicrobial activity of Ageratum conyzoides (Linn) on clinical isolates of Helicobacter pylori," African Journal of Pharmacy and Pharmacology, vol. 3, no. 11, pp. 585-592, 2009.

[24] Z. Lin, Y. Lin, J. Shen et al., "Flavonoids in Ageratum conyzoides L. Exert potent antitumor effects on human cervical adenocarcinoma HeLa cells in vitro and in vivo," BioMed Research International, vol. 2020, Article ID 2696350, 10 pages, 2020.

[25] A. H. Adebayo, N. H. Tan, A. A. Akindahunsi et al., "“'Anticancer and antiradical scavenging activity of Ageratum conyzoides L. (Asteraceae)," pharmacognosy M bnyzoides on alloxan-induced hepatic damage in diabetic wistar rats," Journal of Morphological Sciences, vol. 6, no. 21, pp. 39-45, 2010. 
[26] A. O. Ojewale, H. B. Akpan, F. A. Faduyile et al., "Hepatoprotective activities of ethanolic roots extract of Ageratum conyzoides on alloxan-induced hepatic damage in diabetic wistar, rats," Journal of Morphological Sciences, vol. 36, no. 1, pp. 039-045, 2019.

[27] S. O. Ita, E. O. Akpanyung, B. I. Umoh et al., "Acetaminophen induced hepatic toxicity: protective role of Ageratum conyzoides," Pakistan Journal of Nutrition, vol. 8, no. 7, pp. 928-932, 2009.

[28] R. Varadharajan and D. Rajalingam, "Anti-convulsant activity of methanolic extracts of Ageratum conyzoides L." International Journal of Innovative Drug Discovery, vol. 1, no. 1, pp. 24-28, 2011.

[29] G. C. Jagetia, "Radioprotective potential of plants and herbs against the effects of ionizing radiation," Journal of Clinical Biochemistry and Nutrition, vol. 40, no. 2, pp. 74-81, 2007.

[30] N. E. Nweze and I. Obiwulu, "Anticoccidial effects of $A g$ eratum conyzoides," Journal of Ethnopharmacology, vol. 122, no. 1, pp. 6-9, 2009.

[31] P. A. Akah, C. C. Osigwe, and C. S. Nworu, "Reversal of coumarin-induced toxicity by the extracts and fractions of Ageratum conyzoides," Asian Journal of Medical Sciences, vol. 2, pp. 121-126, 2010.

[32] A. M. Nour, S. A. Khalid, M. Kaiser et al., "The antiprotozoal activity of methylated flavonoids from Ageratum conyzoides L." Journal of Ethnopharmacology, vol. 129, no. 1, pp. 127-130, 2010.

[33] S. O. Ita, E. O. Etim, E. E. Ben, and O. F. Ekpo, "Haematopoietic properties of ethanolic extract of Ageratum conyzoides (goat weed) in albino rats," Nigerian Journal of Physiological Sciences, vol. 22, no. 1-2, pp. 83-87, 2007.

[34] H. P. Singh, D. R. Batish, and R. K. Kohli, "Allelopathic effect of two volatile monoterpenes against bill goat weed (Ageratum conyzoides L.)," Crop Protection, vol. 21, no. 4, pp. 347-350, 2002.

[35] K. J. Achola and R. W. Munenge, "Bronchodilating and uterine activities of Ageratum conyzoides extract," Pharmaceutical Biology, vol. 36, no. 2, pp. 93-96, 1998.

[36] J. Wabo Poné, O. Fossi Tankoua, J. Yondo et al., "The in vitro effects of aqueous and ethanolic extracts of the leaves of Ageratum conyzoides (Asteraceae) on three life cycle stages of the parasitic nematode Heligmosomoides bakeri (Nematoda: heligmosomatidae)," Veterinary Medicine International, vol. 2011, Article ID 140293, 5 pages, 2011.

[37] A. R. Pintong, S. Ampawong, N. Komalamisra et al., "Insecticidal and histopathological effects of ageratum conyzoides weed extracts against dengue vector, Aedes aegypti," Insects, vol. 11, no. 4, p. 224, 2020.

[38] C. J. R. M. do Rosario, C. Q. da Rocha, D. M. de Aguira et al., "Anti-Ehrlichia properties of the essential oil of Ageratum conyzoides L. and its interaction with doxycycline," $A M B$ Express, vol. 9, no. 1, p. 58, 2019.

[39] K. F. Chah, C. A. Eze, C. E. Emuelosi, and C.O. Esimonec, "Antibacterial and wound healing properties of methanolic extracts of some Nigerian medicinal plants," Journal of Ethnopharmacology, vol. 104, no. 1-2, pp. 164-167, 2006.

[40] A. Shirwaikar, P. M. Bhilegaonkar, S. Malini, and J. Sharath Kumar, "The gastroprotective activity of the ethanol extract of Ageratum conyzoides," Journal of Ethnopharmacology, vol. 86, no. 1, pp. 117-121, 2003.

[41] J. O. Igoli, O. G. Ogaji, T. A. Tor-Ayiin, and N. P. Igoli, "Traditional medicine practice amongst the Igede people of Nigeria. Part II," African Journal of Traditional,
Complementary and Alternative Medicines, vol. 2, no. 2, pp. 134-152, 2005.

[42] A. Kamboj and A. K. Saluja, "Isolation of stigmasterol and $\beta$-sitosterol from petroleum ether extract of aerial parts of Ageratum conyzoides (Asteraceae)," International Journal of Pharmacy and Pharmaceutical Sciences, vol. 3, no. 1, pp. 94-96, 2011.

[43] C. F. Bosi, D. W. Rosa, R. Grougnet et al., "Pyrrolizidine alkaloids in medicinal tea of Ageratum conyzoides," Revista Brasileira de Farmacognosia, vol. 23, no. 3, pp. 425-432, 2013.

[44] A. Verma, S. M. Rizvi, S. Shaikh et al., "Compounds isolated from Ageratum houstonianum inhibit the activity of matrix metalloproteinases (MMP-2 and MMP-9): an oncoinformatics study," Pharmacognosy Magazine, vol. 10, no. 37, pp. 18-26, 2014.

[45] E. M. Yousef, M. R. Tahir, Y. St-Pierre et al., "MMP-9 expression varies according to molecular subtypes of breast cancer," BMC Cancer, vol. 14, p. 609, 2014.

[46] B. Fingleton, "MMPs as therapeutic targets-still a viable option?" Seminars in Cell \& Developmental Biology, vol. 19, no. 1, pp. 61-68, 2008.

[47] A. Bahtiar, M. Nurazizah, T. Roselina et al., "Ethanolic extracts of babandotan leaves (Ageratum conyzoides L.) prevents inflammation and proteoglycan degradation by inhibiting TNF- $\alpha$ and MMP-9 on osteoarthritis rats induced by monosodium iodoacetate," Asian Pacific Journal of Tropical Medicine, vol. 10, no. 3, pp. 270-277, 2017.

[48] J. H. SampsonN. G. Bowery et al., "Ethnomedicinally selected plants as sources of potential analgesic compounds: indication of in vitro biological activity in receptor binding assays," Phytotherapy Research: An International Journal Devoted to Pharmacological and Toxicological Evaluation of Natural Product Derivatives, vol. 14, no. 1, pp. 24-29, 2000.

[49] S. M. R. Dewan, M. N. Amin, T. Adnan et al., "Investigation of analgesic potential and in vitro antioxidant activity of two plants of Asteraceae family growing in Bangladesh," Journal of Pharmacy Research, vol. 6, no. 6, pp. 599-603, 2013.

[50] Z. A. Zakaria, Z. D. F. A. Ghani, R. N. Nor et al., "Antinociceptive, anti-inflammatory, and antipyretic properties of an aqueous extract of Dicranopteris linearis leaves in experimental animal models," Journal of Natural Medicines, vol. 62, no. 2, pp. 179-187, 2008.

[51] M. Ferdous, R. Rouf, J. A. Shilpi, and S. J. Uddin, "Antinociceptive activity of the ethanolic extract of Ficus racemosa Lin. (Moraceae)," Oriental Pharmacy and Experimental Medicine, vol. 8, no. 1, pp. 93-96, 2008.

[52] J. F. Marques Neto, L. T. L. Costallat, S. R. M. Fernandes et al., "Efeitos do Ageratum conyzoides, Linèe no tratamento da artrose," Revista Brasileira de Reumatologia, vol. 28, no. 4, pp. 109-114, 1998.

[53] S. K. Tandan, S. Chandra, H. C. Tripathi et al., "Pharmacological effects of ageratum conyzoids roots," Indian Journal of Pharmaceutical Sciences, vol. 56, p. 182, 1994.

[54] D. E. Okwu and C. Josiah, "Evaluation of the chemical composition of two Nigerian medicinal plants," African Journal of Biotechnology, vol. 5, no. 4, pp. 357-361, 2006.

[55] A. M. Agbor, "Methanol extracts of medicinal plants used for oral healthcare in Cameroon," Biochemistry \& Pharmacology Open Access (Los Angel), vol. 4, no. 2, 164 pages, 2015.

[56] M. M. Hassan, A. F. Shahid-Ud-Daula, I. A. Jahan et al., "Anti-inflammatory activity, total flavonoids and tannin content from the ethanolic extract of Ageratum conyzoides linn. Leaf," International Journal of Pharmaceutical and 
Phytopharmacological Research, vol. 1, no. 5, pp. 234-241, 2017.

[57] S. O. Ita, E. E. Francis, A. U. Eda et al., "Anti-inflammation potentials of Ageratum conyzoides against crude oil-induced inflammation and sperm DNA damage in male wistar rats," Journal of Current Medical Research and Opinion, vol. 2, no. 1, pp. 66-71, 2019.

[58] A. Kumar and S. Ghosh, "An experimental evaluation of Ageratum conyzoides on membrane stabilization and protein denaturation during acute inflammation and arthritis," Biomedical and Pharmacology Journal, vol. 4, no. 2, pp. 313-317, 2015.

[59] S. V. G. V. de Mello, J. S. da Rosa, B. M. Facchin et al., "Beneficial effect of Ageratum conyzoides Linn (Asteraceae) upon inflammatory response induced by carrageenan into the mice pleural cavity," Journal of Ethnopharmacology, vol. 194, pp. 337-347, 2016.

[60] P. C. Trinh, L. T. T. Thao, H. T. V. Ha et al., "DPPHscavenging and antimicrobial activities of asteraceae medicinal plants on uropathogenic bacteria," Evidence-Based Complementary and Alternative Medicine, vol. 2020, Article ID 7807026, 9 pages, 2019.

[61] O. A. Omole, J. O. Oladipo, B. O. Orimolade et al., "Antioxidant and anti-microbial activities of the root and leaf extracts of Ageratum conyzoides," Agriculturae Conspectus Scientificus, vol. 84, no. 3, pp. 295-304, 2019.

[62] T. Quoc and L. Pham, "Physicochemical properties and antibacterial activity of essential oil of Ageratum conyzoides L. leaves," Agriculturae Conspectus Scientificus, vol. 85, no. 2, pp. 139-144, 2020.

[63] S. Javed and U. Bashir, "Antifungal activity of different extracts of Ageratum conyzoides for the management of Fusarium solani," African Journal of Biotechnology, vol. 11, no. 49, pp. 11022-11029, 2012.

[64] I. M. Oluchi, O. N. Constance, and O. C. Lilian, "Phytochemicals and antibacterial activity of leaf and stem extracts of Ageratum conyzoides (linn) on some clinical isolates," International Journal of Plant Science and Horticulture, vol. 1, pp. 95-105, 2019.

[65] T. C. Shekhar and G. Anju, "Antioxidant activity by DPPH radical scavenging method of Ageratum conyzoides linn. leaves," American Journal of Ethnomedicine, vol. 1, no. 4, pp. 244-249, 2014.

[66] H. Hossain, U. K. Karmakar, S. K. Biswas et al., "Antinociceptive and antioxidant potential of the crude ethanol extract of the leaves of Ageratum conyzoides grown in Bangladesh," Pharmaceutical Biology, vol. 51, no. 7, pp. 893-898, 2013.

[67] R. P. Patil, M. S. Nimbalkar, U. U. Jadhav et al., "Antiaflatoxigenic and antioxidant activity of an essential oil from Ageratum conyzoides L." Journal of the Science of Food and Agriculture, vol. 90, no. 4, pp. 608-614, 2010.

[68] N. Nyemb, M. D. B. Adèle, N. Njikam et al., "Antioxidant potential of aqueous leaf extract of Ageratum conyzoides Linn. in diabetic rats," Journal of Pharmacognosy and Phytotherapy, vol. 1, no. 4, pp. 41-46, 2009.

[69] V. Ukwe Chinwe, I. Ekwunife Obinna, A. Epueke Ebele et al., "Antimalarial activity of Ageratum conyzoides in combination with chloroquine and artesunate," Asian Pacific Journal of Tropical Medicine, vol. 3, no. 12, 2010.

[70] N. Nyunaï, E. H. Abdennebi, J. Bickii et al., "Subacute antidiabetic properties of Ageratum conyzoides leaves in diabetic rat," International Journal of Pharmaceutical Sciences and Research, vol. 6, no. 4, pp. 1378-1387, 2015.
[71] K. S. Doh and C. B. Aké, "Effect of aqueous extract of Ageratum conyzoides leaves on the glycaemia of rabbits," The Pharma Innovation, vol. 2, no. 8, p. 1, 2013.

[72] S. E. Atawodi, O. A. Adepoju, and H. C. Nzelibe, "Antihyperglycaemic and hypolipidemic effect of methanol extracts of Ageratum conyzoides L (Asteraceae) in normal and diabetic rats," Tropical Journal of Pharmaceutical Research, vol. 16, no. 5, pp. 989-996, 2017.

[73] A. B. Antai, E. U. Eyong, M. U. Eteng et al., "Serum protein and enzyme levels in rats following administration of ethanolic leaf extract of Ageratum conyzoides (goat weed)," Nigerian Journal of Physiological Sciences, vol. 24, no. 2, 2009.

[74] B. M. Agaie, P. Nwatsok, and M. L. Sonfada, "Toxicological effect of the water extract of ageratum conyzoides in rat," Sokoto Journal of Veterinary Sciences, vol. 2, no. 2, pp. 27-31, 2000.

[75] E. Solomon, L. Berg, and D. Martin, Biology, Thomson Brooks/Cole, Belmont, MA, USA, 8th edition, 2008.

[76] C. H. Bhanu Prasad, "A review on drug testing in animals," Translational Biomedicine, vol. 7, no. 4, 2016.

[77] M. R. Fernandes dan and A. R. Pedroso, "Animal experimentation: a look into ethics, welfare and alternative methods," Revista da Associacao Medica Brasileira, vol. 63, no. 11, pp. 923-928, 2017.

[78] G. Zinzalla and D. E. Thurston, “Targeting protein-protein interactions for therapeutic intervention: a challenge for the future," Future Medicinal Chemistry, vol. 1, no. 1, pp. 65-93, 2009.

[79] J. K. Morrow, L. Tian, and S. Zhang, "Molecular networks in drug discovery," Critical Reviews ${ }^{\mathrm{TM}}$ in Biomedical Engineering, vol. 38, no. 2, 2010.

[80] B. K. Yap, C. Y. Lee, S. B. Choi et al., "In silico identification of novel inhibitors," Encyclopedia of Bioinformatics and Computational Biology, Elsevier, Amsterdam, Netherlands, 2019.

[81] X. Lai, H. J. Wichers, M. Soler-López et al., "Phenylthiourea binding to human tyrosinase-related protein 1," International Journal of Molecular Sciences, vol. 21, no. 3, p. 915, 2020.

[82] E. Jortzik, K. Fritz-Wolf, N. Sturm et al., "Redox regulation of Plasmodium falciparum ornithine $\delta$-aminotransferase," Journal of Molecular Biology, vol. 402, no. 2, pp. 445-459, 2010.

[83] R. G. Kurumbail, A. M. Stevens, J. K. Gierse et al., "Structural basis for selective inhibition of cyclooxygenase- 2 by antiinflammatory agents," Nature, vol. 384, no. 6610, pp. 644-648, 1996.

[84] S. B. Richard, M. E. Bowman, W. Kwiatkowske et al., "Structure of 4-diphosphocytidyl-2-C-methylerythritol synthetase involved in mevalonate-independent isoprenoid biosynthesis," Nature Structural Biology, vol. 8, no. 7, pp. 641-648, 2001.

[85] M. Kitamura, M. Okuyama, F. Tanzawa et al., "Structural and functional analysis of a glycoside hydrolase family 97 enzyme from Bacteroides thetaiotaomicron," Journal of Biological Chemistry, vol. 283, no. 52, pp. 36328-36337, 2008.

[86] A. Eldar, H. Rozenberg, Y. Diskin-Posner et al., "Structural studies of p53 inactivation by DNA-contact mutations and its rescue by suppressor mutations via alternative protein-DNA interactions," Nucleic Acids Research, vol. 41, no. 18, pp. 8748-8759, 2013.

[87] P. A. Elkin, Y. S. Ho, W. W. Smith et al., "Structure of the C-terminally truncated human ProMMP9, a gelatin-binding matrix metalloproteinase," Acta Crystallographica Section D: 
Biological Crystallography, vol. 58, no. 7, pp. 1182-1192, 2002.

[88] C. A. Ramsden dan and P. A. Riley, "Tyrosinase: the four oxidation states of the active site and their relevance to enzymatic activation, oxidation and inactivation," Bioorganic \& Medicinal Cchemistry, vol. 22, no. 8, pp. 2388-2395, 2014.

[89] C. Gafan, J. Wilson, L. C. Berger et al., "Characterization of the ornithine aminotransferase from Plasmodium falciparum," Molecular and Biochemical Parasitology, vol. 118, no. 1, pp. 1-10, 2001.

[90] V.S. Hanna and E. A. A. Hafez, "Synopsis of arachidonic acid metabolism: a review," Journal of Advanced Research, vol. 11, pp. 23-32, 2018.

[91] Y. Zhao, J. Yang, B. Qin et al., "Biosynthesis of isoprene in Escherichia coli via methylerythritol phosphate (MEP) pathway," Applied Microbiology and Biotechnology, vol. 90, no. 6, p. 1915, 2011.

[92] S. Imran, M. Taha, N. H. Ismail et al., "Synthesis of novel flavone hydrazones: in-vitro evaluation of $\alpha$-glucosidase inhibition, QSAR analysis and docking studies," European Journal of Medicinal Chemistry, vol. 105, pp. 156-170, 2015.

[93] R. V. Sionov, I. L. Hayon, and Y. Haupt, "The regulation of p53 growth suppression," in Madame Curie Bioscience DatabaseLandes Bioscience, Austin, TX, USA, 2013.

[94] M. Hariono, R. F. Nuwarda, M. Yusuf et al., "Arylamide as potential selective inhibitor for matrix metalloproteinase 9 (MMP9): design, synthesis, biological evaluation, and molecular modeling," Journal of Chemical Information and Modeling, vol. 60, no. 1, pp. 349-359, 2019.

[95] C. F. Adhipandito, D. P. K. S. Ludji, E. Aprilianto et al., "Matrix metalloproteinase9 as the protein target in antibreast cancer drug discovery: an approach by targeting hemopexin domain," Future Journal of Pharmaceutical Sciences, vol. 5, no. 1, p. 1, 2019.

[96] M. Hariono, S. H. Yuliani, E. P. Istyastono et al., "Matrix metalloproteinase 9 (MMP9) in wound healing of diabetic foot ulcer: molecular target and structure-based drug design," Wound Medicine, vol. 22, pp. 1-13, 2018.

[97] S. Jain, N. Jain, A. Tiwari et al., "Simple evaluation of wound healing activity of polyherbal formulation of roots of $\mathrm{Ag}$ eratum conyzoides Linn," Asian Journal of Research in Chemistry, vol. 2, no. 2, pp. 135-138, 2009.

[98] R. Prajapati, S. Roy, S. Mishra et al., "Formulation development, standardization and antimicrobial activity of $\mathrm{Ag}$ eratum conyzoides extracts and their formulation," International Journal of Pharmacy and Pharmaceutical Sciences, vol. 6, no. 2, pp. 369-374, 2014.

[99] A. Budiman, A. N. Azizah, and S. K. Insan, "Antibacterial activity of Ageratum conyzoides L. Extract in gel dosage forms against Staphylococcus epidermidis and Propionibacterium Acne," Pharmacognosy Journal, vol. 12, no. 4, pp. 584-588, 2018.

[100] T. Taufiq and F. Ameilia, "Formulasi dan uji mutu fisik sediaan gel ekstrak etanol herba bandotan (Ageratum conyzoides L.)," Jurnal Kesehatan, vol. 2, no. 2, 2018.

[101] M. Permawati, E. Anwar, A. Arsianti et al., "Anti-inflammatory activity of nanoemulgel formulated from Ageratum conyzoides L. and Oldenlandia corymbosa L. extracts in rats," Journal of Natural Remedies, vol. 19, no. 3, pp. 124-134, 2019. 